\title{
An appraisal on the origin of the Veda
}

\section{- Ram Chandra Paudel}

Veda is considered to be the foundational pillar of Vedic philosophical tradition and culture. The emergence of Vedas precedes the recorded history of man. A commonly held view is that they emerged from the innermost core of Brahma's consciousness at the beginning of creation. Various evidences have been put forward to establish that since Veda is one of the most ancient scriptures, it is the means through which humans can achieve worldly success as well as transcend the materialistic existence through realization of Brahman: the ultimate truth. According to the scholars of Vedas, Brahman is a symbol of Sat-Chit- Ananda (Existence-Consciousness-Bliss) and this is the synonym of Vedas.

Etymological analysis of the word 'veda' reveals that it is formed through the combination of four roots: vid jnane (to know), vid satyama (to attain regime), vid labha (to achieve benefit) and vid bichharane (to gain thoughts). Thus, Veda means knowledge, and knowledge is infinite. To count, categorize and compartmentalize Veda is imprudence and an impossible task comparable to swimming across the vast ocean. Nevertheless, to make the study of Veda a little simple, Moondako council has divided Veda into four parts: Rig Veda, Yajur Veda, SamVeda and Atharva Veda. These four Vedas each have sub categories. They are Aayur Veda, Dhanur Veda, Gaandharva Veda and Sthapattya Veda. The propounders of these sub-vedas are Dhanwantari Vishwamitra, Narad Muni and Biswakarma respectively.

In Manusmriti it is mentioned that Veda is shruti. This is to say at the beginning of creation true knowledge was revealed to the seers which is understood as shruti. 'Shru' means 'to hear' thus the meaning of shruti is knowledge received by hearing. shruti represents corpus of knowledge in oral tradition collected and transmitted by venerated sages of Vedic period which helped to

Bodhi, 3 (1), 120-124. ISSN 2091-0479. (C) 2009 Kathmandu University 
lay the founding stone for the philosophical thought of the world, not just of Hinduism. Shruti is divided into two parts: Vedic and tantrik.

Along with the increase in the interest in Veda in the West and East among scholars and general people, the speculation on whether Veda thus structured into four different parts is created by human mind or is a divine-creation, or/as directly given by God. Some of the thinkers and philosophers of today contradict with the view of general belief of Veda being god-given. They argue that Vedas are like other great epics such as the Mahabharat and the Ramayan written by great seers of the ancient Aryan period. But this claim has been rejected on the ground that at the end of these two scriptures the name of the sages who wrote are mentioned but it is not the case with Vedas. No one is credited for Vedas.

Mimamsakas are seen as the strong supporters of Vedas as divine creation. They have taken a clear stance on this issue and strongly believe that the Vedas are the collection of knowledge seen or felt by the consciousness of the seers-poets of the past. That is why these seers of profound knowledge and mystical power were called mantradrasta (those who can see mantra, 'hymns').

In support of this view, respected Veda scholar, Sayanacharya writes that Veda emerged from the breath of Bramha, so it is divine and is instrumental in the creation of the universe. Respecting and acknowledging Sayanacharya as one of the most learned scholars of vedas, western indiologists have expressed their thoughts in praise of him and Vedas.

The renowned German philosopher, F. M. Muller said about Sayanacharya that if he had not got the opportunity to read writings on Vedas by Sayanacharya, he wouldn't have been able to enter fortress of Vedas and avail himself to the vast treasure of knowledge that it contained. On Vedas Muller said, "In the history of the world, the Vedas fill a gap which no

Bodhi, 3 (1), 120-124. ISSN 2091-0479. (C) 2009 Kathmandu University 
literary work in any other language could fill. I maintain that to everybody who cares for himself, for his ancestor, for his intellectual development, a study of the Vedic literature is indeed indispensable." Like Muller other noted western intellectuals such as Albrecht Weber, Ralph T. H. Griffith, Ruldolf Roth, Arthur B. Keith, and Moriz Winternitz have expressed their appreciation of the opinion held by Sayanacharya on Vedas.

Another Vedas scholar, Yaskacharya, who is considered to be the first aacharya in the history of Vedic grammar, has also clearly mentioned that Vedas are divine creations. He further writes that it is in vain to chant the mantras of Vedas without truly understanding the meaning of them. It is like the animal that carries its burden without knowing what it is. Vedas, which have presented divine thoughts in a simple style, cannot have any other creator than God.

In Mahabharat also it is pointed out that Veda is that which created the universe and it is prehistorical. Vedic Sanatanis believe that word/utterance is timeless. Thus Vedas are timeless as they are the vault of word/utterance. Meanings of Vedas are eternal. Their articulation is also timeless. So there is no doubt that Vedas are divine creation.

In Shivapurana there is a reference to Aum. It is said 'In the beginning was the Supreme word and the word created everything. That word is Aum'. If you are meditating in silence deeply, you can hear the sound Aum within. The whole creation emerged from the sound Aum. It is the primordial or the Universal sound by which the whole universe vibrates. Aum also means inviting the higher energy. This divine sound has the power to create, sustain and destroy, giving life and movement to all that exist. And all four Vedas were produced by this divine sound. The scholars believe that the sound Aum is Parabrahman.

Bodhi, 3 (1), 120-124. ISSN 2091-0479. (C) 2009 Kathmandu University 
In different Hindu scriptures, including Srimadbhagavadgita, Manushmriti and Yajnavalkyasmriti, we find references made in support of Vedas being God-given.

Mimansa followers believe that Vedas emerged on their own. They argue that word is not the creation of any one individual or of god but it came to existence on its own. Thus vedas being the collection of words are self-created.

However, the Nastika philosophy rejects all the evidences in support of Vedas being divine. This philosophy believes that the world is the playground of soul where people's main goal is to satisfy the aspiration of accumulating wealth and sensual desire. Such view puts that the belief in the existence of heaven or hell is baseless or an illusion. In this world there is no God (na parameshwaropi kaschit), neither virtue nor salvation (na dharma: na moksha). Thus, according to this philosophy, there is no question of Vedas being divine.

God, Universe, Life and Nirvana, make the core of all the philosophies that exit in the world or are followed. Aacharya Shree Haribhadra in his scripture Shaddarshan-Smuchhaya has classified six philosophies as Vedic. They are Nyaya, Baisheshika, Samkhya, Yoga, Mimamsa, and Vedanta. Chaarwaka, Buddhism, and Jainaism are avedic or Nastika.

All the aastika philosophies of the world have one guiding principle, atmanam vijnin, that is 'know your soul.' Thus the aspiration to know and to be conscious of Brahman with the single-minded focus of heart and mind should be the final desire of mankind. To achieve this desire, Vedas have prescribed three paths:

Shrotavya: shrutiwakyebhyo mantabyashchopapatthibhi Matya tu satatam dhyeya ete darshana hetawe

(Listening or chanting, thinking/understanding of hymns of Vedas and behaving in noble ways) (Tripathi, 1999)

Bodhi, 3 (1), 120-124. ISSN 2091-0479. (C) 2009 Kathmandu University 
Thus, in unified voice, those scholars who understand and appreciate the value of Vedas say: syustam Veda sa vedawit, that is, individuals who understand that all the living creatures have one and same soul and see no difference between self and other, have the true knowledge of Vedas.

[Translated by Ekku Maya Pun]

\section{Bibliography}

Madhawachaarya. (1883). Jaiminiya nyayamala. Calcutta: Jiwananda Bhattacharya.

Poddar, Hanuman Prashad (Ed.). (1999). Veda-Kathanka Gorakhpur: Gita press

Rai, Gangasagar (Ed.). (n.d.). Yagyabalkyasmriti. Delhi: Prachyabharati, Chaukhamba Sanskrita Pratisthan.

Royal Nepal Academy. (1976). Lokayata Darshan . Kathmandu

Sayanachaarya. (1959). Taittiriya Samhita $\left(2^{\text {rd }} \quad\right.$ ed. $), \quad$ Puna: Anandashram.

Shankaracharya. (2003). Mundakopanishada. Gorakhpur: Gita press.

Sharma, Gopikrishna. (1996). Sanskrit sahityako ruprekha. Kathmandu: Abhinav.

Vedvyas. (1999). Shrimadbhagavata $\left(38^{\text {th }}\right.$ ed.). Gorakhpur: Gita press.

Vedvyas. (2003). Shrimadbhagavadgita ( ${ }^{\text {th }}$ ed.). Gorakhpur: Gita press.

Bodhi, 3 (1), 120-124. ISSN 2091-0479. (C) 2009 Kathmandu University 